\title{
Current Technologies for the Prevention of Parastomal Herniation (Review)
}

\author{
DOI: $10.17691 / \mathrm{stm} 2018.10 .3 .22$
}

Received January 17, 2018

A.A. Yanishev, Assistant, Department of General Surgery named after A.I. Kozhevnikov;

A.V. Bazaev, MD, DSc, Head of the Department of General Surgery named after A.I. Kozhevnikov;

A.R. Kokobelyan, MD, PhD, Associate Professor, Department of General Surgery named after A.I. Kozhevnikov; A.I. Abelevich, MD, DSc, Professor, Department of General Surgery named after A.I. Kozhevnikov

${ }^{1}$ Privolzhsky Research Medical University, 10/1 Minin and Pozharsky Square, Nizhny Novgorod, 603005, Russia

In today's colorectal surgery, the number of ostomy patients is steadily increasing. The creation of a stoma often leads to the development of a parastomal hernia, which, in turn, can cause serious complications and prevent full rehabilitation of the patient. Most often, parastomal hernias are formed within two years after surgery, but the possibility of herniation still exists throughout the entire postoperative period.

In the present review, we describe the up-to-date methods used to prevent parastomal hernias as well as the results of clinical studies and meta-analyses. When discussing the surgical techniques, emphasis is put on their safety, efficacy and economic rationale.

Key words: parastomal hernia; intestinal stoma; colostomy; ileostomy; mesh endoprosthesis.

The gradual increase in the incidence of colorectal cancer and other colon diseases leads to an increase in the number of surgical interventions associated with the creation of an intestinal stoma [1-9]. Each year, in the United States alone, about 100,000 people undergo surgery with the formation of an ileo- or colostoma [10]. Likewise, in the Russian Federation, the number of ostomy patients reaches $120,000-140,000[11,12]$.

The creation of a stoma is a risk factor for the development of a parastomal hernia [13], i.e. the protrusion of abdominal organs into the hernial sac through the opening in the anterior abdominal wall, created by the surgeon to form the stoma [14].

The incidence of parastomal hernias is estimated as $28.3 \%$ with permanent end ileostomy and $48 \%$ with permanent end colostomy [15]. In most cases, a parastomal hernia is formed within the first two years after surgery, but the possibility of herniation persists throughout the entire postoperative period. Some authors even believe the development of parastomal hernias is inevitable [16]. Usually, the stoma creation is not the major step in this type of surgery, yet for the patient, the problem of stoma care goes first $[17,18]$.
Parastomal hernias in both ileo- and colostomy [19-25] often prevent full rehabilitation of the patient and can seriously affect the patient's quality of life. It was noted that in patients with a parastomal hernia, the risk of stoma-associated complications is significantly higher than that in patients with hernia-free ostomy [26-29]. There are ways to correct or prevent parastomal herniation, yet this type of hernias remains a serious surgical challenge $[15,17,30]$. Among the major causes of parastomal herniation, are technical errors in the process of stoma creation [31-33]. Hence, the problem can be solved by improving the stoma-related technique so to prevent the hernia formation [34].

It is believed that the chances of herniation are largely determined by the site of stoma location on the anterior abdominal wall. When the stoma canal is made through the sheath of the straight abdominal muscle, the chances of parastomal herniation are less than that with the pararectal access [35].

There are several options for guiding a bowel segment through the abdominal straight muscle. In the traditional approach, the front sheet of the straight muscle sheath is cross-cut, and the posterior sheet of the sheath together

Corresponding author: Aleksey A. Yanishev, e-mail: lex565@yandex.ru 
with the straight muscle is split vertically to form a stoma. Another option is the placement of the stoma close to the lateral edge of the straight muscle sheath (lateral rectus abdominis positioned stoma, LRAPS) [36, 37]. In this method, a horizontal cut is made on the front sheet of the straight muscle sheath, and then it is moved medially. The posterior sheet is then cut horizontally to form a stoma [38]. A study on 72 patients with a median follow-up of 24 months showed that the risk of parastomal herniation after the LRAPS is about $10 \%$ as compared with 40-60\% with the traditional method [36]. However, in a review of nine retrospective cohort studies [39], totaling 761 patients, there was no difference in the rate of herniation between the pararectal and transrectal techniques (relative risk: $1.29 \%$, confidence interval: 95\%), although the reviewers indicated the incompleteness of the reviewed reports where variable techniques were used. A meta-analysis by Carne [15] showed that only 4 out of 24 studies demonstrated a lower chance of parastomal herniation when the straight muscle access was used. Thus, the relationship between the stoma location and the chances of parastomal herniation remains uncertain $[14,16,40]$.

Another issue that continues to be discussed in the literature is the size of incision made to form the stoma canal $[17,41,42]$. In a study on 33 patients by Pilgrim et al. [43], an excessively long incision of the aponeurosis was associated with the development of a parastomal hernia. The authors concluded that every additional millimeter of the aponeurosis incision increased the risk of subsequent herniation by $10 \%$.

The main requirement for such an incision is the tight encompassing of the bowel without creating ischemic conditions there; however, this criterion remains subjective and difficult to compare between different studies [44-46]. It is commonly known that even if the diameter of the bowel segment selected for the stoma ideally fits the fascial incision size, the latter tends to expand with time. This dilatation is especially pronounced in elderly patients, those with diabetes, oncological patients, and people with increased intraabdominal pressure associated with abdominal obesity, benign prostatic hyperplasia or chronic cough [47-49]. In addition, similar to the enlargement of the hernial defect in postoperative hernia [50], the dilatation of the stoma canal can be due to metabolic abnormalities in the connective tissue associated with either genetic factors or the prolonged existence of the abdominal wall defect [51].

One way of preventing parastomal herniation is the strengthening of tissue diastasis between the fascial aperture of the stoma canal and the bowel segment that forms the stoma [52]. In this approach, the entire perimeter of the stoma canal is enforced with the help of endoprostheses. In this respect, an original surgical method (without using mesh implants) has been proposed. Instead of using a cross cut for the formation of a stoma canal (by Lyon and Smith [53]), a straight- line incision of the aponeurosis has been suggested; in this technique, the corners of the aponeurosis are fixed with two interrupted stitches made of a non-absorbable suture material. In a group of 25 patients treated this way and followed-up for 12 months (median), no parastomal herniation was found [54]. Together with a good efficacy, the suggested method is safe and cost-effective as compared with other methods of hernia prevention, where mesh prostheses, bio-implants or special devices are used.

There is evidence that suturing the stoma-carrying bowel segment to the anterior abdominal wall prevents the formation of a parastomal hernia. So, von Smitten et al. [55] reported on 54 patients with an end sigmoid stoma; in half of these patients, the stoma was created by using this technique. No significant difference between the two sub-groups was found. Abcarian and Pearl argue against fixing the bowel because this modification has not been clinically confirmed [56]. Thus, the available data are insufficient to support or disprove the hypothesis that closing the lateral space by tying the stoma-carrying bowel segment to the anterior abdominal wall reduces the risk of subsequent parastomal herniation [15]

In 1958, Goligher and Sames simultaneously described an extraperitoneal way of creating an end stoma [57-59]. In this technique, a retroperitoneal canal is created along the anterior abdominal wall by peeling the peritoneum off the muscular aponeurotic layer to the point where the stoma would optimally attach to the anterior abdominal wall. This approach protects the peritoneum on the inner side of the stoma canal. The similar anatomical and physiological considerations were described by Sugarbaker regarding the surgical treatment of a parastomal hernia [16].

Hamada et al. analyzed the data of 37 patients; 22 of them underwent laparoscopic abdominal-perineal extirpation and creation of a retroperitoneal stoma [60]. According to the results of this retrospective study, only $4.5 \%$ of such patients (with extraperitoneal approach) developed parastomal herniation as compared with $33 \%$ in transperitoneal colostomy $(p=0.03)$. The similar conclusion was made in the meta-analysis of 1000 patients made by Lian et al. [61]. It was found that after the open surgery, the occurrence rate of parastomal herniation around a retroperitoneal stoma was significantly lower $(p=0.002)$ than that with the traditional technique. In addition, the proposed technique is associated with a decrease in the occurrence of stoma prolapses and bowel obstruction. There are no obvious shortcomings in this retroperitoneal technique, except that it is often necessary to mobilize the left flexure of the colon to obtain a bowel segment long enough to create a stoma. Despite the promising results [47], extraperitoneal stomas have not yet been recommended for common use even for the formation of permanent stomas [16]. The authors agree that further studies are needed to evaluate the efficacy of this method in preventing parastomal hernias [15]. 
In 1977, Rosin and Bonardi [62] proposed using mesh prosthesis to strengthen the stoma canal. In 1986, Bayer et al. [63] published the first results of strengthening the anterior abdominal wall using mesh prosthesis for the formation of colostomy.

To date, many types of mesh-based implants are used for the prevention and treatment of parastomal hernias. Most often, they are made of polypropylene, especially its large-pore light version $[64,65]$. In addition, a number of composite implants that contain biodegradable anti-adhesive components are available [48, 66-71]. No complications were found after using two-component prosthesis [72]. It was also noted that the large-pore implants reduced the risk of inflammation in the abdominal organs located in the close vicinity [11].

When the mesh is implanted to prevent herniation, the surgeon should carefully consider the position of the aponeurosis defect (in this case, the stoma canal). The "onlay" modification is most commonly used: in this case, the implant is placed over the aponeurosis defect $[64,67]$. In the "sublay" approach, the mesh is placed under the edges of the aponeurosis defect (in the retromuscular, preperitoneal way [65, 69-71] or intraperitoneally $[48,66,71])$. The size of the prosthesis should be at least $10 \mathrm{~cm}$, and it should overlap the anterior abdominal wall by at least $5 \mathrm{~cm}$ [16]. In most studies related to the prophylactic use of the mesh prosthesis, parastomal hernias developed after open surgeries [73, 74] where small-sized (less than $6 \times 6 \mathrm{~cm}$ ) flat mesh implants were used [75]. When the endoprosthesis is placed in direct contact with the organs of the abdominal cavity or the intestinal loops, it can lead to the formation of fistulas, adhesions or strictures [76].

Prophylactic mesh implantation is performed both with the open and laparoscopic operations; usually, this step adds about 30 min to the duration of the surgical intervention [64]. Recent meta-analyzes and systematic reviews have shown a reduction in the incidence of clinically detectable parastomal hernias after the installation of prophylactic mesh implants as compared with the operations without prostheses (10.8-24.4\% $[77,78]$ vs $36-94 \%[79,80])$. In recent studies, there has been no difference in the incidence of infectious complications and the severity of pain between the surgery interventions with and without an endoprosthesis $[73,74,81,82]$.

Jones et al. [73] who performed preventive implantation of the mesh prosthesis in the sublay mode with a median follow-up of 5 years, reported a $13.3 \%$ incidence of parastomal herniation versus $81 \%$ in the control group.

In a study by Goncharov et al. [83], the median followup was 20.0-25.5 months. They found that a modified version of the Sugarbaker's operation with using a composite allograft in the initial intervention reduced the incidence of parastomal hernias 5-fold; the authors suggested their approach was safe and could be used to prevent parastomal herniation. However, the necessity of the preventive manipulations remains controversial, since $73 \%$ of patients in the control group (no hernia preventive measures) developed no parastomal hernias during the observation period.

The development of parastomal hernias after abdominoperineal rectal extirpation was the subject of a randomized multicenter clinical trial conducted in Finland [71]. For the purpose of hernia prevention, a two-component composite endoprosthesis was attached to the peritoneum. According to CT scans, there was no significant difference in the occurrence rate of hernia formation between the groups. However, upon a visual examination, the cases of parastomal hernias prevailed in the control group $(32.3 \%)$ as compared with the endoprosthesis group $(14.3 \%) \quad(p<0.05)$. This study once again demonstrated the importance of using both the clinical and instrumental tests in the diagnosis of parastomal hernias.

By today, the efficacy of a mesh implant inserted during a primary laparoscopic operation in preventing parastomal herniation has been well documented. In a randomized clinical trial, Serra-Aracil et al. [70] implanted a hernia-prevention mesh endoprosthesis using a modified Sugarbaker's approach. The hernial protrusion was tested with abdominal CT scans. The authors detected parastomal hernias in $25 \%$ of patients in the experimental group and $64 \%$ in the control group.

In the randomized controlled PREVENT study [84], a light mesh prosthesis was installed in the sublay/ retromuscular position to prevent parastomal herniation. The short-term results showed that only 3 of 67 patients in this group and 16 of 66 patients in the control group had parastomal hernias. No other differences between the groups (infectious complications, pain syndrome, or additional postoperative hernias) were found.

Lykke et al. [85] assessed the safety and efficacy of paracolostomy hernia prevention by using mesh prosthesis in emergency surgery. In $48 \%$ of cases, the operation field was contaminated. Despite this, half of the patients underwent preventive mesh implantation. Even with the contaminated operating field, there was no difference in the development of wound complications. In addition, with an observation median of 12 months, the incidence of parastomal herniation in the experimental and control groups was the same.

It is believed that a contamination of the operating field can occur from time to time after the surgical ileostomy or colostomy; however, in this assessment, a differentiated approach is required. Under conditions when the operating field is infected, the use of bioimplants (much more expensive than synthetic) is preferable because of their lower susceptibility to bacterial contamination [16]. In addition, bioimplants significantly reduce the risk of intestinal parastomal fistulas due to a lower rate of bowel erosion. In clinical practice, Permacol and Strattice bioprostheses made of pig skin, devoid of antigenic structure and chemically crosslinked, are widely used. As 
a result of the manufacturing process, an implant made of this material contains pure cross-linked collagen and elastin without cellular structures or adipose tissue [86, 87]. Initially, it was reported that the use of bioimplants significantly reduced the frequency of parastomal hernias, although this claim was based on a small number of studies involving a small number of patients $[88,89]$. The multicenter prospective randomized PAISM trial contradicted the initial results. The PAISM compared patients whose end stoma was formed according to the standard procedure, with patients in whom it was reinforced with the help of a Strattice bio-implant, placed in the sublay position [90]. The bioimplant was laid anteriorly to the posterior sheet of the rectus abdominis sheath, the stoma-carrying bowel segment was passed through a cross-like incision. After 24 months of observation, there was no significant difference in the formation of parastomal hernia between the main group $(10.2 \%)$ and control (13\%). The authors concluded that the strengthening of the stoma canal with the help of mesh bioimplants is safe, but not economically justified for routine prevention [90].

Thus, recent clinical studies and meta-analyzes on the preventive use of mesh implants have yielded promising results. However, in most studies, there was an insufficient number of patients, so the probability of statistical errors was high [79]. Additional contradictions resulted from the reports where no significant difference in the incidence of parastomal hernias was found between the groups without and with the mesh endoprostheses [85]. In this regard, extra caution is recommended when extrapolating the published data into practical clinical decisions [91].

Another promising method of preventing parastomal hernias is the use of staplers to form a stoma. In the traditional manual stoma creation, the technical skills of the surgeon have a decisive role; the use of staplers though can help standardize the procedure and make its use more universal, which will eventually reduce the number of complications [92].

For the first time, a device for the stoma formation was suggested by Resnick in 1986 [93]. At present, a number of modifications of the original method are in use. In 2011, Williams et al. [94] published the first data on the application of the SMART technique (stapled mesh stoma reinforcement technique), which involved the stapling of a bio-implant to the posterior sheet of the rectus abdominis sheath. For this purpose, a specially designed sewing instrument, similar to the standard circular EEA stapler, was used. With this technology, a reinforced hole sized at 17 to $30 \mathrm{~mm}$ is created in the fascial layer. The bioprosthesis is attached by a circular interrupted stapler suture to the outer sheet of the rectus abdominis muscle sheath. The primary data obtained in non-randomized controlled trials showed a significant reduction in parastomal herniation when this technique was used, $19 \%$ versus $73 \%(p<0.04)$ [95].

A similar method was tested by a group from Australia
( $\mathrm{Ng}$ and Tan [96]); unlike Williams they used a standard circular stapling machine with a diameter of 25 and $28 \mathrm{~mm}$ and the Ultrapro composite mesh prosthesis. The latter was circularly fixed to the inner sheet of the abdominal straight muscle sheath. The excess of the mesh implant was sutured to the posterior sheet interrupted stitches. The stoma-carrying bowel segment was passed through this stoma canal. Two patients out of 14 developed parastomal hernias (as revealed by $\mathrm{CT}$ ); those did not require surgical treatment. There were no complications associated with the stoma [96]. The long-term results of this methodology are not presented but expected to be assessed in future studies.

Thus, the problem of choosing a method for preventing parastomal herniation becomes important. To date, there are several effective evidence-based methods of prevention. Studies on the efficacy of using mesh endoprostheses continue. In some clinics, they are already used in routine practice [38].

As indicated by the reviewed reports, the use of mesh polymeric endoprostheses in the treatment of ventral hernias reduces the risk of hernia recurrence but leads to an increase in the risk of wound complications [97101]. In this regard, it is possible that the preventive installation of mesh implants aimed at reducing the risk of parastomal hernia will increase the risk of wound complications around the stoma. This assumption is confirmed by studies indicating an increase in stomaassociated infections after a mesh implant was used for the stoma formation [102-104]. It was also noted that in $52-73 \%$ of patients with a permanent end colostomy, parastomal hernias did not develop [15, 83]. We believe that in the presence of several alternative methods of parastomal hernia prevention, implantation of mesh endoprostheses to all patients with permanent stoma is not necessary, because such a procedure would expose a significant group of patients to an increased risk of complications. Further studies are needed to identify patients with different chances of developing parastomal hernias and to rationalize the strategy of prevention.

Financial support. The study was not funded by any sources.

Conflict of interest. The authors have no conflicts of interest to be reported.

\section{References}

1. Ayoupov R.T. Modern approaches to the advanced colorectal cancer treatment. Kreativnaya khirurgiya $i$ onkologiya 2010; 3: 32-36.

2. Davydov M.I., Aksel E.M. Statistika zabolevaemosti i smertnosti ot zlokachestvennykh novoobrazovaniy v 2000 g. V kn.: Zlokachestvennye novoobrazovaniya $v$ Rossii $i$ stranakh SNG v $2000 \mathrm{~g}$. [Statistics of morbidity and mortality rate for malignant neoplasms in 2000. In: Malignant neoplasms in Russia and CIS countries in 2000] Moscow: RONTs im. N.N. Blokhina RAMN; 2002; p. 85-106.

3. Timerbulatov M.V., Gaynutdinov F.M., Ibatullin A.A., 
Kulyapin A.V. Treatment of rectal cancer, current trends. Zdravookhranenie Bashkortostana 2008; 7: 15-18.

4. Toychuev Z.M., Gataullin I.G., Aglullin I.R., Khamitov M.R., Kaji M.R. Prevention of paracolostomal complications following abdominoperineal extirpation of the rectum. Kazanskij medicinskij zurnal 2012; 93(5): 725-728.

5. Statistics of malignant neoplasms in Russia and CIS countries in 2009. Davydov M.I., Aksel E.M. (editors). Vestnik RONTs im. N.N. Blokhina RAMN 2011; 22(3, Suppl. 1).

6. Chissov V.I., Petrova G.V., Starinskiy V.V., Kharchenko N.V., Gretsova O.P. Morbidity rate for malignant neoplasms among the population in Russia in 2000. Rossijskij onkologiceskij zurnal 2000; 3: 39-44.

7. Poddubnaya I.V., Aksel E.M., Kipriyanova N.S. Complex analysis of cancer incidence among population of Yakutsk (1990-2003). Sibirskiy onkologicheskiy zhurnal 2007; 2: 55-62.

8. Moskovchenko A.N., Groshilin V.S., Dudarev S.I. Possibilities of correction of functional results of imposing singlebarreled colon's sty. Ul'yanovskiy mediko-biologicheskiy zhurnal 2015; 3: 48-51.

9. Zlokachestvennye novoobrazovaniya $v$ Rossii $v$ 2001 g. [Malignant neoplasms in Russia in 2001]. Pod red. Chissova V.I., Starinskogo V.V., Petrovoy G.V. [Chissov V.I., Starinskiy V.V., Petrova G.V. (editors)]. Moscow: Meditsina; 2003; 234 p.

10. Hendren S., Hammond K., Glasgow S.C., Perry W.B., Buie W.D., Steele S.R., Rafferty J. Clinical practice guidelines for ostomy surgery. Dis Colon Rectum 2015; 58(4): 375-387, https://doi.org/10.1097/dcr.0000000000000347.

11. Sukhanov V.G. Sotsial'naya reabilitatsiya patsientov so stomoy [Social rehabilitation of patients with a stoma]. Moscow: Nauka; 2006

12. Nazarova D.A. Investigation, analysis and development of practical recommendations for the nursing care of patients with intestinal stoma. RUDN Journal of Medicine 2017; 21(3): 347-355, https://doi.org/10.22363/2313-0245-2017-21-3-347355.

13. Śmietański M., Bury K., Matyja A., Dziki A., Wallner G., Studniarek M., Fridiger J., Szczepkowski M., Świerblewski M., Wróblewski T., Tarnowski W., Solecki R., Mitura K. Polish guidelines for treatment of patients with parastomal hernia. Pol Przegl Chir 2013; 85(3): 152-180, https://doi.org/10.2478/pjs2013-0027.

14. Shelygin Yu.A., Achkasov S.I., Moskalev A.I. Natsional'nye klinicheskie rekomendatsii po gerniologii [National clinical guidelines on herniology]. Moscow; 2017.

15. Carne P.W., Robertson G.M., Frizelle F.A. Parastomal hernia. $\mathrm{Br} J$ Surg 2003; 90(7): 784-793, https://doi. org/10.1002/bjs.4220.

16. Glasgow S., Dharmarajan S. Parastomal hernia: avoidance and treatment in the $21^{\text {st }}$ century. Clin Colon Rectal Surg 2016; 29(3): 277-284, https://doi. org/10.1055/s-0036-1584506.

17. Ermolaev E.I. Comparative assessment of colostomy results. Meditsina i ekologiya 2010; 4: 182-184.

18. Kurdukova P.G., Popov I.P., Popova N.V. Late colostomy complications. Byulleten' Vostochno-Sibirskogo nauchnogo tsentra Sibirskogo otdeleniya Rossiyskoy akademii meditsinskikh nauk 2006; 5: 354-355.

19. Vorob'ev G.I., Tsar'kov P.V. Osnovy khirurgii kishechnykh stom [Fundamentals of bowel stoma surgery]. Moscow: Stol'nyy grad; 2002.
20. Kald A., Juul K.N., Hjortsvang H., Sjödahl R.I. Quality of life is impaired in patients with peristomal bulging of a sigmoid colostomy. Scand J Gastroenterol 2008; 43(5): 627-633, https://doi.org/10.1080/00365520701858470.

21. Krogsgaard M., Pilsgaard B., Borglit T.B., Bentzen J., Balleby L., Krarup P.M. Symptom load and individual symptoms before and after repair of parastomal hernia: a prospective single centre study. Colorectal Dis 2017; 19(2): 200-207, https://doi.org/10.1111/codi.13403.

22. Scarpa M., Ruffolo C., Boetto R., Pozza A., Sadocchi L., Angriman I. Diverting loop ileostomy after restorative proctocolectomy: predictors of poor outcome and poor quality of life. Colorectal Dis 2010; 12(9): 914-920, https://doi. org/10.1111/j.1463-1318.2009.01884.x.

23. Dalgatov G.M., Zagirjv U.Z., Zagirova N.N., Isaev U.M., Salikhov M.A. Medico-social rehabilitation of colostomed patients. Vestnik novyh medicinskih tehnologij 2007; 14(4): $114-115$.

24. Kosovan V.N. Quality of life assessment in patients with a formed stoma of the colon. Klinichna hirurgija 2012; 9: 9-11.

25. Gyul'mamedov P.F. Curative bowel stomas: indications, tactics, complications (our esperience). Aktual'ni problemy suchasnoi' medycyny 2007; 7(1-2): 107-109.

26. Aquina C.T., lannuzzi J.C., Probst C.P., Kelly K.N., Noyes K., Fleming F.J., Monson J.R. Parastomal hernia: a growing problem with new solutions. Dig Surg 2014; 31(4-5): 366-376, https://doi.org/10.1159/000369279.

27. Chikinev Y.V., Zadilsky R.P. Late complications by colostomies, formed in the conditions of intestinal obstruction. Meditsina i obrazovanie $v$ Sibiri 2015; 3: 39.

28. Leong A., Londono-Schimmer E., Phillips R. Lifetable analysis of stomal complications following ileostomy. Br J Surg 1994; 81(5): 727-729, https://doi.org/10.1002/ bjs. 1800810536.

29. Lobakov A.I. Rehabilitation of patients with postoperative curative bowel stomas. Hirurgia 2006; 5: 12-14.

30. Shakeev K.T. Colostomy complications. Meditsina $i$ ekologiya 2008; 4: 91-25.

31. Shaposhnikov V.I., Ashhamaf M.H., Zorik V.V., Marchenko N.V., Gedzyun R.V. Analisis of technical inaccuracy shaping concave kolostom. Kubanskiy nauchnyy meditsinskiy vestnik 2013; 3: 139-141.

32. Stoyko Yu.M., Manikhas G.M., Khanevich M.D., Konovalov S.V. Profilaktika i lechenie oslozhneniy kolostom [Prevention and treatment of colostoma complications]. Saint Petersburg: Agraf+; 2008.

33. Ibatullin A.A., Timerbulatov M.V., Gaynutdinov F.M., Kulyapin A.V., Bulatov R.R., Ibatullin R.T. Analysis of unsatisfactory outcomes of ostomy raising surgeries. Byulleten' Vostochno-Sibirskogo nauchnogo tsentra Sibirskogo otdeleniya Rossiyskoy akademii meditsinskikh nauk 2007; 4(56): 85-86.

34. Timerbulatov M.V., Ibatullin A.A., Gaynutdinov F.M., Kulyapin A.V., Aitova L.R., Kyzylbaeva A.I., Abdeev A.A., Fatkhullin A.S. Late stomal complications and their surgical correction. Kazanskij medicinskij zurnal 2012; 93(4): 602-606.

35. Sjödahl R., Anderberg B., Bolin T. Parastomal hernia in relation to site of the abdominal stoma. Br J Surg 1988; 75(4): 339-341, https://doi.org/10.1002/bjs.1800750414.

36. Evans M.D., Thomas C., Beaton C., Williams G.L., McKain E.S., Stephenson B.M. Lowering the incidence of stomal herniation: further follow up of the lateral rectus 
abdominis positioned stoma. Colorectal Dis 2011; 13(6): 716717, https://doi.org/10.1111/j.1463-1318.2011.02635.x.

37. Stephenson B.M., Evans M.D., Hilton J., McKain E.S., Williams G.L. Minimal anatomical disruption in stoma formation: the lateral rectus abdominis positioned stoma (LRAPS). Colorectal Dis 2010; 12(10): 1049-1052, https://doi. org/10.1111/j.1463-1318.2009.02178.x.

38. Schein's common sense: prevention and management of surgical complications. Schein M., Rogers P.N., Leppäniemi A., Rosin D. (editors). Shropshire: TFM Publishing Limited; 2013; 558 p.

39. Hardt J., Meerpohl J.J., Metzendorf M.I., Kienle P., Post S., Herrle F. Lateral pararectal versus transrectal stoma placement for prevention of parastomal herniation. Cochrane Database Syst Rev 2013, https://doi.org/10.1002/14651858. cd009487.pub2.

40. Kroese L.F., de Smet G.H., Jeekel J., Kleinrensink G.J., Lange J.F. Systematic review and meta-analysis of extraperitoneal versus transperitoneal colostomy for preventing parastomal hernia. Dis Colon Rectum 2016; 59(7): 688-695, https://doi.org/10.1097/dcr.0000000000000605.

41. Kalashnikova I.A., Achkasov S.I. Algorithm of diagnosis and treatment of bowel stoma complications. Koloproktologiya 2009; 3: 8-15.

42. Yermolayev I.Ye. The colostomy complications. Meditsina i ekologiya 2010; 4: 37-41.

43. Pilgrim C., McIntyre R., Bailey M. Prospective audit of parastomal hernia: prevalence and associated comorbidities. Dis Colon Rectum 2010; 53(1): 71-76, https://doi.org/10.1007/ dcr.0b013e3181bdee8c.

44. Shakeev K.T., Nurbekov A.A., Zhanasova M.M. Assessing the efficacy of colostomy prevention method. Vestnik khirurgii Kazakhstana 2010; 1: 70-71.

45. Atlas of intestinal stomas. Fazio V.W., Church J.M., Wu J.S. (editors). Springer US; 2012, https://doi. org/10.1007/978-0-387-78851-7.

46. Volenko A.V., Andreyev Yu.V., Volenko I.A., Andreyev V.G. Comparative analysis of application of sutureless colostomy in colon surgery. Byulleten' VostochnoSibirskogo nauchnogo tsentra Sibirskogo otdeleniya Rossiyskoy akademii meditsinskikh nauk 2011; 4-2: 29-31.

47. Londono-Schimmer E.E., Leong A.P., Phillips R.K. Life table analysis of stomal complications following colostomy. Dis Colon Rectum 1994; 37(9): 916-920, https://doi.org/10.1007/ bf02052598.

48. López-Cano M., Lozoya-Trujillo R., Quiroga S., Sánchez J.L., Vallribera F., Martí M., Jiménez L.M., ArmengolCarrasco M., Espín E. Use of a prosthetic mesh to prevent parastomal hernia during laparoscopic abdominoperineal resection: a randomized controlled trial. Hernia 2012; 16(6): 661-667, https://doi.org/10.1007/s10029-012-0952-z.

49. Nastro P., Knowles C.H., McGrath A., Heyman B., Porrett T.R., Lunniss P.J. Complications of intestinal stomas. Br J Surg 2010; 97(12): 1885-1889, https://doi.org/10.1002/ bjs.7259.

50. Parshikov V.V., Fedaev A.A. Abdominal wall prosthetic repair in ventral and incisional hernia treatment: classification, terminology and technical aspects (review). Sovremennye tehnologii $v$ medicine 2015; 7(2): 138-152, https://doi. org/10.17691/stm2015.7.2.19.

51. Bogdan V.G., Gain Yu.M. Pathogenesis of incisional hernias: connective tissue metabolism change - cause or effect? Novosti khirurgii 2011; 6: 29-35.
52. Fedorov V.D., Dul'tsev Yu.V. Proktologiya [Proctology] Moscow: Meditsina; 1984; 384 p.

53. Abdominal stomas and their skin disorders. An atlas of diagnosis and management. Lyon C.C., Smith A.J. (editors). UK: Informa; 2010, https://doi.org/10.3109/9780203443996.

54. Hayles K., Almoudaris A. Reducing the incidence of parastomal hernia with a simple surgical technique. Br J Nurs 2017; 26(5): S4-S10, https://doi.org/10.12968/ bjon.2017.26.5.s4.

55. von Smitten K., Husa A., Kyllönen L. Long-term results of sigmoidostomy in patients with anorectal malignancy. Acta Chir Scand 1986; 152: 211-213.

56. Abcarian H., Pearl R.K. Stomas. Surg Clin North Am 1988; 68(6): 1295-1305, https://doi.org/10.1016/s00396109(16)44687-6.

57. Goligher J.C. Extraperitoneal colostomy or ileostomy. Br J Surg 1958; 46(196): 97-103, https://doi.org/10.1002/ bjs. 18004619602 .

58. Sames C.P. Extraperitoneal colostomy. Lancet 1958; 271(7020): 567-568, https://doi.org/10.1016/s01406736(58)91197-8.

59. Elliot-Smith A., Painter N.S. Experiences with extraperitoneal colostomy and ileostomy. Gut 1961; 2(4): 360362, https://doi.org/10.1136/gut.2.4.360.

60. Hamada M., Ozaki K., Muraoka G., Kawakita N., Nishioka Y. Permanent end-sigmoid colostomy through the extraperitoneal route prevents parastomal hernia after laparoscopic abdominoperineal resection. Dis Colon Rectum 2012; 55(9): 963-969, https://doi.org/10.1097/ dcr.0b013e31825fb5ff.

61. Lian L., Wu X.R., He X.S., Zou Y.F., Wu X.J., Lan P., Wang J.P. Extraperitoneal vs. intraperitoneal route for permanent colostomy: a meta-analysis of 1,071 patients. Int J Colorectal Dis 2012; 27(1): 59-64, https://doi.org/10.1007/ s00384-011-1293-6.

62. Rosin J.D., Bonardi R.A. Paracolostomy hernia repair with Marlex mesh: a new technique. Dis Colon Rectum 1977; 20(4): 299-302, https://doi.org/10.1007/bf02586428.

63. Bayer I., Kyzer S., Chaimoff C. A new approach to primary strengthening of colostomy with Marlex mesh to prevent paracolostomy hernia. Surg Gynecol Obstet 1986; 163(6): 579-580.

64. Gögenur I., Mortensen J., Harvald T., Rosenberg J., Fischer A. Prevention of parastomal hernia by placement of a polypropylene mesh at the primary operation. Dis Colon Rectum 2006; 49(8): 1131-1135, https://doi.org/10.1007/ s10350-006-0615-1.

65. Brandsma H.T., Hansson B.M., Aufenacker T.J., van Geldere D., van Lammeren F.M., Mahabier C., Steenvoorde P., de Vries Reilingh T.S., Wiezer R.J., de Wilt J.H., Bleichrodt R.P., Rosman C. Prophylactic mesh placement to prevent parastomal hernia, early results of a prospective multicentre randomized trial. Hernia 2016; 20(4): 535-541, https://doi.org/10.1007/s10029-015-1427-9.

66. Gataullin I.G., Toychuyev Z.M., Aglullin I.R. Comparative results of end colostomy for low rectal cancer using alloplastic material. Onkologicheskaya koloproktologiya 2012; 4: 32-36.

67. Hauters P., Cardin J.L., Lepere M., Valverde A., Cossa J.P., Auvray S. Prevention of parastomal hernia by intraperitoneal onlay mesh reinforcement at the time of stoma formation. Hernia 2012; 16(6): 655-660, https://doi. org/10.1007/s10029-012-0947-9. 
68. Jänes A., Cengiz Y., Israelsson L.A. Randomized clinical trial of the use of a prosthetic mesh to prevent parastomal hernia. Br J Surg 2004; 91(3): 280-282, https://doi. org/10.1002/bjs.4417.

69. Jänes A., Cengiz Y., Israelsson L.A. Preventing parastomal hernia with a prosthetic mesh: a 5-year follow-up of a randomized study. World J Surg 2009; 33(1): 118-121, https://doi.org/10.1007/s00268-008-9785-4.

70. Serra-Aracil X., Bombardo-Junca J., Moreno-Matias J., Darnell A., Mora-Lopez L., Alcantara-Moral M., AyguavivesGarnica I., Navarro-Soto S. Randomized, controlled, prospective trial of the use of a mesh to prevent parastomal hernia. Ann Surg 2009; 249(4): 583-587, https://doi. org/10.1097/sla.0b013e31819ec809.

71. Vierimaa M., Klintrup K., Biancari F., Victorzon M., Carpelan-Holmström M., Kössi J., Kellokumpu I., Rauvala E., Ohtonen P., Mäkelä J., Rautio T. Prospective, randomized study on the use of a prosthetic mesh for prevention of parastomal hernia of permanent colostomy. Dis Colon Rectum 2015; 58(10): 943-949, https://doi.org/10.1097/ dcr.0000000000000443.

72. Conde-Muíño R., Díez J.L., Martínez A., Huertas F., Segura I., Palma P. Preventing parastomal hernias with systematic intraperitoneal specifically designed mesh. BMC Surg 2017; 17(1): 41, https://doi.org/10.1186/s12893-017-0237-7.

73. Jänes A., Cengiz Y., Israelsson L.A. Experiences with a prophylactic mesh in 93 consecutive ostomies. World J Surg 2010; 34(7): 1637-1640, https://doi.org/10.1007/s00268-0100492-6.

74. Janson A.R., Jänes A., Israelsson L.A. Laparoscopic stoma formation with a prophylactic prosthetic mesh. Hernia 2010; 14(5): 495-498, https://doi.org/10.1007/s10029-0100673-0

75. Vijayasekar C., Marimuthu K., Jadhav V., Mathew G. Parastomal hernia: is prevention better than cure? Use of preperitoneal polypropylene mesh at the time of stoma formation. Tech Coloproctol 2008; 12(4): 309-313, https://doi. org/10.1007/s10151-008-0441-7.

76. Israelsson L.A. Preventing and treating parastomal hernia. World J Surg 2005; 29: 1086-1089, https://doi. org/10.1007/s00268-005-7973-z.

77. Chapman S.J., Wood B., Drake T.M., Young N., Jayne D.G. Systematic review and meta-analysis of prophylactic mesh during primary stoma formation to prevent parastomal hernia. Dis Colon Rectum 2017; 60(1): 107-115, https://doi.org/10.1097/dcr.0000000000000670.

78. Wang S., Wang W., Zhu B., Song G., Jiang C. Efficacy of prophylactic mesh in end-colostomy construction: a systematic review and meta-analysis of randomized controlled trials. World J Surg 2016; 40(10): 2528-2536, https://doi. org/10.1007/s00268-016-3576-0.

79. Cross A.J., Buchwald P.L., Frizelle F.A., Eglinton T.W. Meta-analysis of prophylactic mesh to prevent parastomal hernia. Br J Surg 2017; 104(3): 179-186, https://doi. org/10.1002/bjs.10402.

80. Pianka F., Probst P., Keller A.V., Saure D., Grummich K., Büchler M.W., Diener M.K. Prophylactic mesh placement for the prevention of parastomal hernias: the PRESTO systematic review and meta-analysis. PLoS One 2017; 12(2): e0171548, https://doi.org/10.1371/journal.pone.0171548.

81. Toychuyev S.M., Gataullin I.G., Aglullin I.R. Way of prevention of paracolostomal hernias. Povolzhskiy onkologicheskiy vestnik 2012; 4: 56-59.
82. Shakeev K.T. Rezul'taty lecheniya pozdnikh parakolostomicheskikh oslozhneniy. Vestnik khirurgii Kazakhstana 2008; 4(16): 36-39.

83. Goncharov A.L., Razbirin V.N., Shalaeva T.I., Cherner V.A., Razbirin D.V., Gurova O.V., Aslanyan A.S. Prevention of paracolostomic hernia. Khirurgiya. Zhurnal im. N.I. Pirogova 2016; 10: 52-56, https://doi.org/10.17116/ hirurgia20161052-56.

84. Brandsma H.T., Hansson B.M., Aufenacker T.J., van Geldere D., Lammeren F.M., Mahabier C., Makai P., Steenvoorde P., de Vries Reilingh T.S., Wiezer M.J., de Wilt J.H., Bleichrodt R.P., Rosman C.; Dutch Prevent Study group. Prophylactic mesh placement during formation of an end-colostomy reduces the rate of parastomal hernia: short-term results of the Dutch PREVENT-trial. Ann Surg 2017; 265(4): 663-669, https://doi.org/10.1097/ sla.0000000000001903.

85. Lykke A., Andersen J., Jorgensen L.N., Mynster T. Prevention of parastomal hernia in the emergency setting. Langenbecks Arch Surg 2017; 402(6): 949-955, https://doi. org/10.1007/s00423-017-1596-3.

86. Permacol ${ }^{\mathrm{TM}}$ Surgical Implant. Instructions for use.

87. Kaleya R.N. Evaluation of implant/host tissue interactions following intraperitoneal implantation of porcine dermal collagen prosthesis in the rat. Hernia 2005; 9(3): 269276, https://doi.org/10.1007/s10029-005-0003-0.

88. Hammond T.M., Huang A., Prosser K., Frye J.N., Williams N.S. Parastomal hernia prevention using a novel collagen implant: a randomized controlled phase 1 study. Hernia 2008; 12(5): 475-481, https://doi.org/10.1007/s10029008-0383-z.

89. Figel N.A., Rostas J.W., Ellis C.N. Outcomes using a bioprosthetic mesh at the time of permanent stoma creation in preventing a parastomal hernia: a value analysis. Am J Surg 2012; 203(3): 323-326, https://doi.org/10.1016/j.amjsurg.2011. 10.006.

90. Fleshman J.W., Beck D.E., Hyman N., Wexner S.D., Bauer J., George V.; PRISM Study Group. A prospective, multicenter, randomized, controlled study of non-cross-linked porcine acellular dermal matrix fascial sublay for parastomal reinforcement in patients undergoing surgery for permanent abdominal wall ostomies. Dis Colon Rectum 2014; 57(5): 623631, https://doi.org/10.1097/dcr.0000000000000106.

91. Cornille J.B., Pathak S., Daniels I.R., Smart N.J. Prophylactic mesh use during primary stoma formation to prevent parastomal hernia. Ann R Coll Surg Engl 2017; 99(1): 2-11, https://doi.org/10.1308/rcsann.2016.0186.

92. Zhang P., Bai J., Shuai X., Chang W., Gao J., Liu X., Wang G., Tao K. Circular stapler-assisted extraperitoneal colostomy in laparoscopic abdominoperineal resection: a single surgeon experience. J Gastrointest Surg 2016; 20(3): 619-623, https://doi.org/10.1007/s11605-015-3039-1.

93. Resnick $\mathrm{S}$. New method of bowel stoma formation. Am J Surg 1986; 152(5): 545-548, https://doi.org/10.1016/00029610(86)90226-6.

94. Williams N.S., Nair R., Bhan C. Stapled mesh stoma reinforcement technique (SMART) - a procedure to prevent parastomal herniation. Ann R Coll Surg Engl 2011; 93(2): 169172, https://doi.org/10.1308/003588411x12851639107313d.

95. Williams N.S., Hotouras A., Bhan C., Murphy J., Chan C.L. A case-controlled pilot study assessing the safety and efficacy of the stapled mesh stoma reinforcement technique (SMART) in reducing the incidence of parastomal 
herniation. Hernia 2015; 19(6): 949-954, https://doi. org/10.1007/s10029-015-1346-9.

96. Ng Z.Q., Tan P., Theophilus M. Stapled mesh stoma reinforcement technique (SMART) in the prevention of parastomal hernia: a single-centre experience. Hernia 2017; 21(3): 469-475, https://doi.org/10.1007/s10029-016-1548-9.

97. Vlasov A.V., Kukosh M.V. The problem of wound complications in abdominal wall endoprosthesis replacement in ventral hernias. Sovremennye tehnologii v medicine 2013; 5(2): 116-124.

98. den Hartog D., Dur A., Tuinebreijer W.E., Kreis R.W. Open surgical procedures for incisional hernias. Cochrane Database Syst Rev 2008; 16(3): CD006438, https://doi. org/10.1002/14651858.cd006438.pub2.

99. Usov S.A., Nosov V.G. Wound infection after incisional hernias prosthetic repair: the review of foreign papers of last decade. Byulleten' Vostochno-Sibirskogo nauchnogo tsentra Sibirskogo otdeleniya Rossiyskoy akademii meditsinskikh nauk 2006; 6: 221-225.

100. Aleksandrenkov N.V., Mukhin A.S., Rebtsovskiy V.A.,
Leont'ev A.E. Wound closure method at subaponeurotic plasty with polypropylene mesh of large postoperative ventral hernia. Novosti khirurgii 2013; 1: 88-93, https://doi.org/10.18484/23050047.2013.1.88.

101. Korenkov M., Sauerland S., Paul A., Neugebauer E.A. Incisional hernia repair in Germany at the crossroads: a comparison of two hospital surveys in 1995 and 2001. Zentralbl Chir 2002; 127(8): 700-704.

102. Geisler D.J., Reilly J.C., Vaughan S.G., Glennon E.J., Kondylis P.D. Safety and outcome of use of nonabsorbable mesh for repair of fascial defects in the presence of open bowel. Dis Colon Rectum 2003; 46(8): 1118-1123, https://doi. org/10.1007/s10350-004-7290-x.

103. Morris-Stiff G., Hughes L. The continuing challenge of parastomal hernia: failure of a novel polypropylene mesh repair. Ann R Coll Surg Engl 1998; 80(3): 184-187.

104. Steele S.R., Lee P., Martin M.J., Mullenix P.S., Sullivan E.S. Is parastomal hernia repair with polypropylene mesh safe? Am J Surg 2003; 185(5): 436-440, https://doi. org/10.1016/s0002-9610(03)00040-0. 